\title{
Má školní vzdělávání smysl, jestliže nevede k hledání smyslu?
}

\author{
Ludmila Muchová
}

K čemu jsme na světě? Tak zněla první otázka katechismu, za níž následovala i jasná a stručná odpověd', když se šestileté děti posadily na první hodinu katolického náboženství ještě v padesátých letech 20. století. $\vee$ té době už ovšem takových dětí bylo velmi málo. Ani v současné době jich nijak nepřibývá. Náboženství už prakticky není integrální součástí života školy ani v podobě př́slušného předmětu, ani v podobě společných rituálů či obecně sdíleného pohledu na svět. Zưstává však někde v prostoru české školy „,viset ve vzduchu“ naléhavost výzvy, která je v té otázce obsažena? Patři k úkolům školy pomoci dětem a mladým lidem hledat na ni odpověd', když žiji své školní i mimoškolní životy uprostřed hodnotově a světonázorově pluralitní společnosti, která nenabízí na složité otázky jednoduché odpovědi? Výzva hledat smysl života, který se skrývá za touto otázkou, není záležitost pouze jednotlivcủ, již od dětství ho hledáme ve společenství blízkých i vzdálenějších lidí. Jak dnešní děti a mladí lidé hledají, o co $\checkmark$ životě skutečně jde, a jak jim v tom pomáhá škola?

Tento článek si klade za cíl přispěł k promýšlení vzájemného vztahu mezi českým školstvím, současnou společností a hledáním životního smyslu dětí i lidí angažovaných $\checkmark$ českých školách. Na jedné straně chci ukázat na úskalí současných kurikulárních dokumentů vzhledem k výchovné a vzdělávací pomoci dětem na cestě hledání smyslu života, na druhé straně chci upozornit na skutečnost, že v českém pedagogickém prostoru se lze oprít o jasnou představu o obsahu pojmu životní smysl (vybírám k tomu psychoterapeutický směr logoterapie), a na existující evaluační nástroje, které jsou současně vydatnou pomocí školám k zaměření pozornosti na tento úkol. Na první pohled by se pritom mohlo zdát, že zde není př́liš prostoru k hlubokomyslným analýzám a hledání závěrů. Vztah mezi společností a jejím školstvím je dán řadou oficiálních dokumentů, které opakovaně stvrzují, že škola slouží - vedle dalších prostředkü - ke stabilizaci přitomné i budoucí společnosti. Česká společnost a české školství v tom nejsou výjimkou. Vyjdeme-li z charakteristiky současné společnosti, často nazývané postmoderní (či hypermoderní, viz např. G. Lipovetsky)' nebo vnímané jako vyústění modernity (např. A. Giddens)², můžeme se opřit o dva její znaky: globalizaci a individualismus.

\section{Smysl života jako hodnota v postmoderní společnosti}

Anthony Giddens vymezuje pět rozměrů globalizace. Především je to světová kapitalistická ekonomika. Oddělení politické a ekonomické moci v jednotlivých státech umožnilo podle něho globální aktivity nadnárodních korporací, které z pozice ekonomické moci ovlivňují politiku v jednotlivých zemích. Skutečnost, že produkují pro zisk, je hnacím motorem rozšiřování jejich trhů se zbožím a trhů peněžních. Současně s nimi souvisí i globální nerovnosti ve vztahu k lidem jako k pracovním silám. Jednotlivé státy bohatnou či chudnou v souvislosti s růstem ekonomiky a od jejich bohatství se odvozuje i jejich význam v celosvětovém politic-

1 Srov. Gilles LIPOVETSKY, Hypermoderní doba: od prožitku k úzkosti, Praha: Prostor, 2013.

2 Srov. Anthony GIDDENS, Důsledky modernity, Praha: Sociologické nakladatelství, 2003. 
kém řádu. Vzájemnou koordinací a propojováním sice slábne jejich individuální suverenita, ale zvyšuje se jejich moc, a tím i význam. To je druhá dimenze globality. Třetí dimenze - globální vojenský rád - v sobě nese tytéž protikladné tendence. Vojenské aliance nadnárodního charakteru (např. NATO) omezují možnost členských zemí vytvářet navenek vlastní vojenské strategie, ale propůjčují jim podíl na moci celé aliance. Dramatickým problémem je ohromná ničivá schopnost moderních válečných technologií, které udržují na vysoké úrovni nejen ekonomicky vyspělé země světa, ale i země chudé. Giddens se domnívá, že v tomto smyslu neexistuje žádný „trřetí svět", ale pouze svět první. Na ničivost moderních zbraní ukázaly už 1. i 2. světová válka, $v$ éře zbraní hromadného ničení má však držení těchto zbraní význam jak symbolický, tak odstrašující. Čtvrtou dimenzí globalizace je podle tohoto autora mezinárodní dělba práce. Původní propojenost národních ekonomik s vlastními nerostnými zdroji a kvalifikace pracovních sil s tradičními typy průmyslu byly nahrazeny po 2. světové válce globální dělbou práce, $\mathrm{v}$ jejíž podstatě je umožnění výroby $\mathrm{v}$ tradičně chudých zemích, které vzhledem ke svým podmínkám nabídly především velmi levnou pracovní sílu. Mnohé ekonomicky silné země tak byly $\mathrm{v}$ podstatě odindustrializovány a dnes mají problém s organizací vlastních ekonomik. Rozvoj průmyslu a průmyslových technologií však ovlivňuje i jiné oblasti - např̀. prostřednictvím zemědělství dochází $\mathrm{k}$ ničení životního prostředí, které znamená vzhledem ke globální propojenosti světa skutečně planetární ohroženost. Poslední, pátou dimenzi nazývá Giddens globalizací kulturní, jejíž vznik umožnila transformace komunikačních technologií. V jejich důsledku jsou lidé na celém světě nejen systematicky informováni o událostech na opačných pólech Země, ale především se díky nim instituce modernity šîrí skutečně globálně po celém světě. ${ }^{3}$

Není těžké zařadit $\mathrm{v}$ rámci těchto dimenzí Českou republiku. Z vojenského a politického mocenského seskupení ve sféře vlivu Sovětského svazu, na kterém se dohodly vítězné mocnosti na konci 2. světové války, přešla republika po roce 1989 velmi rychle a na bázi dobrovolnosti do nového politického uskupení Evropské unie a vojenského uskupení NATO. V rámci EU potom sledujeme i v Čechách ekonomický růst jako veledůležitý ukazatel našeho významu na globální politické scéně. Platí-li známý výrok Marie Terezie, že škola je politikum, potom není divu, že Evropská unie (a s ní i naše země) usiluje ze všech sil o to, aby zvyšovala svou konkurenceschopnost na celosvětovém trhu práce, a tak rozmnožovala své bohatství, které zpětně podmiňuje technický, vojenský i industriální pokrok. Bez vzdělané a dostatečně flexibilní pracovní síly toho není možné dosáhnout. Pracovní síla, která ovlivní naše šance v budoucnosti počítané na desetiletí, sedí momentálně ve školních lavicích. Především jejich učení je tedy potřeba ovlivnit tímto směrem.

Úsilí politiků, kteří rozhodují o směřování země a mají $\mathrm{k}$ tomu dostatek rozhodovacích pravomocí, se na základě úvah o globalizovaném světě zdá logické. Chce však také toto všechno občan, tedy jednotlivec, individuum? Potřebuje dnešní člověk ke spokojenému životu, aby byl součástí mocného, významného a bohatého celku? Odpověd' můžeme nalézt v úvahách, které se odvíjejí právě od jednotlivce a od jeho významu v současné společnosti. V této souvislosti bývá naše společnost označována jako společnost individualistická.

Individualismus má podle slovenského autora O. Štefaňaka v postsocialistických zemích střední Evropy své specifické rysy. Po r. 1989 se podle něho začaly vytvářet nové subkultury, pro které byl př́źnačný zejména trend rychlého kulturního osamostatňování, vytváření vlastního životního stylu, módy, zvláštní hodnotové orientace a partnerství (Štefaňak to ukazuje na mládeži). To byla podle něho př́má cesta $\mathrm{k}$ individualismu, díky kterému chápe každý 


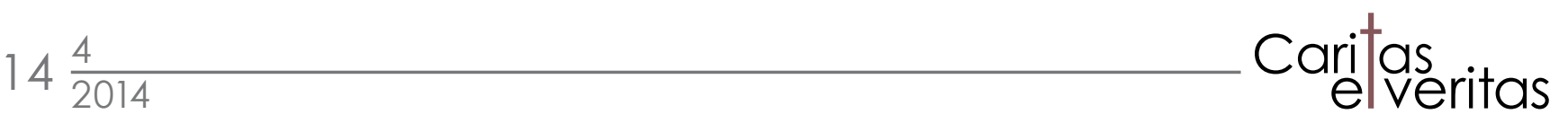

člověk sám sebe jako tvůrce svého života a zároveň jako konzumenta svého vlastního projektu. Díky masovému přístupu k vyšším formám vzdělání se prodlužuje doba mládí. Zejména mladí lidé tak cítí tlak na to, aby se sami stali tvưrci své vlastní identity. Podle Štefaňaka je tedy každý člověk nucen formovat svůj život díky vlastním autonomním a zcela osobním rozhodnutím. S notnou dávkou nedůvěry sleduje velké instituce, od nichž dříve lidé přejímali životní hodnoty, normy a vzory chování jako závazky, aniž by uvažovali o jejich platnosti. Samotná autonomie v rozhodování se dnes stává vysoce ceněnou hodnotou vedle hodnot typu seberealizace, kreativita nebo víra v lidský pokrok. Účast na životě velkých institucí je vnímána jako dobrovolný závazek platící pouze na „určitou dobu“. Štefaňak podtrhuje osamělost, která se může stát součástí takto vnímaného úkolu postupného skládání vlastní identity jevem tzv. "scén“, což jsou místa společného setkávání lidí, na nichž se sice lidé dostávají do vzájemného fyzického kontaktu, ale pouze za účelem dosažení nějakého partikulárního cíle, což nevyžaduje vystoupení $\mathrm{z}$ anonymity. Zdůrazňování individuality vede některé lidi $\mathrm{k}$ představě sociální rovnosti. Vzestup na společenském žebřičcku však není dán pouze pílí, nadáním a kvalitou autonomních rozhodnutí, ale především ekonomickým a sociálním rodinným kapitálem, tedy finanční movitostí rodičů a jejich kontakty na sít lidí zastávajících určité funkce. Hledání svobody má podle Štefaňaka jak pozitivní, tak negativní rysy. Zejména mladí lidé tak protestují proti nejrůznějším druhům násilí nebo se angažují v humanitních či ekologických kampaních. Na druhé straně se snaží zorientovat ve společnosti, kterou sociologové nazývají „společnost anomická“, tj. společnost bezzákonná: Její cíle jsou nejasné, protože selhávají dosavadní morální přesvědčení, je oslabeno kolektivní vědomí, začíná se projevovat rozdíl mezi skutečnými prostředky jednotlivců a kulturní a sociální nabídkou společnosti. To vše může vést ke ztrátě vztahu lidí ke společnosti. Díky dělbě práce se také ztrácejí vzájemné vztahy mezi lidmi. Svou moc také ztrácí sociální kontrola. Štefaňak dodává, že pro slovenskou společnost (a zdá se, že obdobně to platí i pro společnost českou) je charakteristický intenzivní sociální tlak na úspěch, ale méně intenzivní tlak na používání morálních prostředků k jeho dosažení. Lidé tedy v daleko větší míře sahají k nelegálním prostředkům. Prostředí konkurence ruku v ruce s rozpadem institucí, které měly vzhledem $\mathrm{k}$ jednotlivcům ochrannou funkci, tak způsobují degradaci lidství a lidskosti ve společnosti. ${ }^{4}$

Hodnota lidské svobody realizované ve vlastním autonomním rozhodování, od které se odvíjí zdůrazňování individualismu v současné společnosti, tak vykazuje jistou dvojsečnost. Může vést $\mathrm{k}$ odpovědné kritice a protestům vůči politikům a institucím v př́ípadě, že se jejich rozhodování obrací proti člověku, současně však může být prostředkem na cestě k dosahování úspěchu bez akceptování morálních závazků či ohledů. Vůbec jsme si mohli všimnout, že v sociologické úvaze o globalizaci a jejích projevech byla morální dimenze jednání politiků, podnikatelů, ekonomů či provozovatelů komunikačních technologií ponechána stranou. Naopak v životě jednotlivce, který se sám rozhoduje pro volbu svých životních cílů i prostředků, jak jich dosáhnout, hraje ústřední roli. Jak tedy právě tato hodnota souvisí se smyslem lidského života?

Dílo rakouského lékaře a psychoterapeuta V. E. Frankla vznikalo a tříbilo se v období vrcholícího, či spíše zanikajícího moderního věku - v 1. polovině 20. století, zejména během 2. světové války, jejíž trauma zažíval coby židovský vězeň čtyř koncentračních táborů. Jeho poznání tedy nevzniklo v době ustavující se postmoderny nijak náhodně. Bylo výsledkem důsledného promýšlení př́ičin ničivých mocenských a vražedných mechanismů, k jejichž realizaci se propůjči-

4 Srov. Ondrej ŠTEFAŇAK, Religiozita mládeže na príklade spišskej diecézy, Ružomberok: PF KU v Ružomberku, 2009, s. 52-53. Štefaňakova analýza velmi dobře odpovídá nejčastějším charakteristikám postmodernity, jak je popisuje i A. Giddens. Srov. Anthony GIDDENS, Důsledky modernity, s. 133-134. 
li lidé vrcholícího moderního věku. Franklova odpověd' však nevyznívá depresivně. Naopak. Když sleduje podstatnou otázku po štěstí člověka, odpovídá na základě řady empirických zjištění, že člověk má přirozenou potřebu štěstí, které neplyne z jeho vlastního prospěchu či uspokojení, ale naopak z toho, do jaké míry usiluje o dobro někoho či něčeho, co leží mimo jeho vlastní osobu. Pocit uspokojení a radosti tak podle něho zažívá člověk, který plní nějaký úkol spojený s prací pro druhé lidi nebo pro svět, který se setkává s druhými lidmi či světem v citu jedinečné lásky nebo v zážitku krásy, a konečně člověk, který odpovídá svým přijímajícím postojem na utrpení a bolest. Naplňování hodnot lásky, dobra, krásy, odpuštění apod. shrnuje Frankl pod zastřešující úkol člověka: naplnit svůj život smyslem. A právě v tomto lidském životním principu spatřuje jeho logoterapie duchovní rozměr existence člověka. ${ }^{5}$ Shrnuje ho výstižně E. Lukasová: „Člověk je myslící by tost a jako nositel duchovní dimenze nedokáže jen spotřebovávat a užívat si. To mu prostě k duševnímu zdraví a vnitřnímu naplnění nestačí.“"

E. Lukasová je př́má žákyně V. E. Frankla. Třináct let se zabývala přímo poradenskou činností. Myšlenky logoterapie a existenciální analýzy proto aplikovala také na problém vzdělání a výchovy dětí $\mathrm{k}$ životnímu smyslu. Shrňme stručně její logoterapeutické podněty pro výchovu a vzdělávání dětí a mladých lidí. E. Lukasová ukazuje, jak člověk svým myšlením, cítěním a jednáním dosahuje vždy zároveň mimo sebe, jak dospívá k sebetranscendenci. Staví se před řadu možností, $\mathrm{z}$ nichž může uskutečnit vždy pouze některé. Výchova by ho měla vést $\mathrm{k}$ tomu, aby dokázal volit ty nejsmysluplněǰš - tedy ty, které vedou nikoliv pouze k uspokojování vlastní slasti či k pozorování pouze vlastních pocitů nebo tělesných či duševních stavů, ale ty, které vedou $\mathrm{k}$ vlastnímu přesahu v práci, $\mathrm{v}$ lásce, $\mathrm{v}$ setkání s krásou či v postoji vůči utrpení. Ohrožení člověka současné postmoderní doby potom vidí Lukasová právě v přebytku, který dovoluje lidem prvního světa hlavně spotřebovávat nebo se pasivně bavit; extrémně vyjádřeno - s plným žaludkem a tučným bankovním účtem sedět ve vlastním přepychovém bytě a nemít už žádná přání, protože všechna jsou v zápětí splnitelná prostřednictvím peněz.

Pro zdravý vývoj vlastního vztahu k hodnotám spojeným s naplňováním životního smyslu potřebují dnešní děti a mladí lidé podle Lukasové především, aby jim dospělá generace pomohla vidět svět jejich her a učení ve smysluplných souvislostech, potřebují vědomí hodnoty věcí kolem sebe, potřebují úkol, kterému stojí za to věnovat síly, aby vytvořili nějaký konstruktivní záměr. Od pouhého konzumování mají být děti vedeny k cílevědomé činnosti, k níž mohou přispívat svými nápady a svou prací a kterou mohou proměňovat $\mathrm{v}$ tvưrčí proces při vytváření něčeho, co leží mimo ně samé. Výchovu chápe logoterapie jako přípravu na dospělost, ve které už vychovatelská generace nemůže od dospělých dětí odejmout nejrůznějš́ krize a problémy. Výchova je př́íprava na život $\mathrm{v}$ tom smyslu, že vede dospívající generaci $\mathrm{k}$ práci a odpovědnosti. Orientace na výkon přitom např́klad ve školním vzdělávání není logoterapií zavržena, je však podřízena cíli dát dětem do života co nejvíce možností, jak naplnit svůj život smyslem tím, že rozvinou do nejvyšší míry své talenty ve službě nějaké dobré věci. Výchova má dodávat dětem především odvahu k životu, za tím účelem je má chránit před př́liš velkým množstvím nezdravých vlivů a pomáhat jim vytvářet svůj vlastní životní styl. Úspěch výchovy a vzdělávání není skryt pouze ve výsledcích výkonnostních testů, ale také v tom, jak se děti a mladí lidé naučí ve škole "uchopit život" ${ }^{\prime \prime}$

5 Celé Franklovo dílo rozvíjí popsané tři cesty člověka k naplnění života smyslem. Za všechny jmenujme např. Viktor Emanuel FRANKL, Vůle ke smyslu: vybrané přednášky o logoterapii, Brno: Cesta, 1997 nebo Viktor Emanuel FRANKL, Lékařská péče o duši: základy logoterapie a existenciální analýzy, Brno: Cesta, 2006. V českém křest'anském prostředí rozvíjí Franklovy myšlenky zejména P. Tavel. Srov. např. Peter TAVEL, Smysl života podle Viktora Emanuela Frankla: potřeba smyslu života, př́nos Viktora E. Frankla k otázce smyslu života, Praha: Triton, 2007.

6 Elisabeth LUKASOVÁ, Logoterapie ve výchově, Praha: Portál, 1997, s. 40.

7 Srov. tamtéž, s. 56-112. 
Vidíme, že jednoznačný závěr plynoucí z politicko-ekonomického zájmu společnosti obstát v konkurenci na světovém trhu, zajistit tak svým občanům co největší blahobyt a podřídit tomu i samotný školský systém naráží v úvahách logoterapeutů na zjištění, že bohatý člověk vězící v blahobytu ještě nemusí být spokojený, radostný a št'astný, jestliže nedokáže uchopit život tak, aby dospěl k hodnotám, které ho přesahují. Protože člověk není pouze konzument či pasivní účastník dějů, které probíhají mimo jeho vůli, ve své duchovní dimenzi chce být spolutvưrcem světa a št'astného života lidí kolem sebe. Logoterapie to nazve jednoduše: hledat a nalézat životní smysl. A vyzve pedagogy, aby tomuto záměru podřídili své výchovné a vzdělávací snahy. Jak odpovídá na tuto skutečnost, že radost, spokojenost a štěstí lidstva není spojeno pouze s úspěchem na trhu zboží a práce, české školství?

\section{Neoliberální reformy školských systémů Evropské unie a jejich ekonomické pozadí}

Podle mezinárodního srovnání znalostí PISA (Programme for International Student Assessment) 2009 zaznamenali čeští žáci největší zhoršení svých výkonů oproti předcházejícím obdobím ze všech 65 zkoumaných zemí, a to v oblasti čtenářských, matematických a přírodovědných dovedností. V roce 2012 se potom jen velmi mírně tyto schopnosti zlepšily, ovšem $\mathrm{v}$ jejich úrovni zůstali čeští žáci spíše v oblasti průměru. Naopak na předních místech se v poslední době umíst'ují žáci z asijských zemí: Šanghaj, Singapur nebo Hongkong. V obou letech většina českých žáků v přiloženém dotazníku shodně uváděla, že do školy nechodí ráda, že se tam často nudí, někteří by tam dokonce nejraději nechodili vůbec. Ze zemí OECD jsou na tom čeští žáci nejhưřre co do hodnocení školy jako přátelského prostředí. Naopak jejich výkony jsou ve srovnání s jinými vyspělými zeměmi OECD daleko závislejší na socioekonomickém zázemí vlastních rodin. ${ }^{8}$ Česká veřejnost je s podobnými výsledky seznamována každé tři roky, pravidelně se k neradostným výsledkům vyjadřují úřadující ministři školství, kteří argumentují nízkou finanční podporou školství, projevující se zejména na nízkých platech učitelů a na špatné úrovni jejich dalšího vzdělávání. Výsledky testů zkoumá také Ceská školní inspekce, která má za úkol navrhnout změny v tom smyslu, aby se výkony našich žáků v budoucnosti zlepšily.

Málokdo si přitom všimne, jaká mezinárodní organizace za pravidelným testováním znalostních dovedností dětí v 65 zemích světa stojí. Za zkratkou OECD se skrývá název „Organizace pro hospodářskou spolupráci a rozvoj”. Založena byla v roce 1961 jako nástupnická organizace po své předchůdkyni, jejímž úkolem byla hospodářská obnova zemí Evropy po 2. světové válce. Skládá se z 34 ekonomicky nejvyspělejších zemí světa. Její hlavní činností je prosazování tržních principů v různých oblastech ekonomického života. ČR je jejím členem od roku $1995 .{ }^{9}$ Jestliže se tedy tato organizace zajímá o úroveň vzdělání žáků a studentů v různých zemích světa, je její zorný úhel pohledu zaměřen zcela jistě na vztah mezi úrovní vzdělání a ekonomickou prosperitou zemí, které se v globalizované společnosti dostávají do ostré konkurence vzhledem k jiným zemím a světadílům. Jak jsme konstatovali v předcházející kapitole, globalizace a neoliberalistické tendence jsou hybnými pákami současné postmoderní společnosti. Za tlakem na vyšší úroveň znalostí, které umí žáci aplikovat v praxi, se tedy skrývají otázky spojené s optimalizací lidských výkonů, a tím zkvalitnění jejich nabídky pro trh práce, na němž vládne stále ostřejší konkurence.

8 Srov. (C) Čeští žáci se v mezinárodním srovnání průzkumu PISA zlepšili (on-line), dostupné na: http://www.ceskenoviny.cz/zpravy/cestizaci-se-v-mezinarodnim-srovnani-pisa-zlepsili/1015298, citováno dne 16. 5. 2014.

9 Srov. ( ) MINISTERSTVO ŠKOLSTVÍ, MLÁDEŽE A TĚLOVÝCHOVY, Informace o zapojení České republiky do vzdělávacích projektů OECD (on-line), dostupné na: http:/ / www.msmt.cz/mezinarodni-vztahy/organizace-pro-ekonomickou-spolupraci-a-rozvoj-oecd, citováno dne 16. 6. 2014. 
Ostatně historie české Bílé knihy, národního programu rozvoje vzdělávání v České republice ukazuje na svou svázanost s podobnými cíli, s jakými OECD sleduje změny v úrovni vzdělání v důležitých zemích světa. Česká Bílá kniha navazuje pro změnu na dokument Evropské unie, který nese název Bílá kniha o obecném a odborném vzdělávání - učit a učit se - na cestě ke kognitivní společnosti. Abychom dobře porozuměli jejímu smyslu, musíme se vrátit k její historii.

$\mathrm{V}$ rámci Evropské unie jsou pravidelně vydávány tzv. zelené knihy sloužící k co nejširší diskusi o určité politické oblasti (např. péči o životní prostředí nebo o energetické politice pro Evropskou unii). Bílé knihy obsahují návrhy pro aktivity společnosti v určité oblasti. Někdy navazují na zelené knihy, ale obsahují již oficiální návrhy k určitým politickým oblastem a slouží k tomu, aby země Evropské unie tyto oblasti rozvíjely určitým směrem. Bílá kniha týkající se školské politiky zemí Evropské unie vyšla v roce 1995. Navázala na bílou knihu z r. 1993 nesoucí název Růst, schopnost konkurence, zaměstnanost, která položila důraz na tzv. „,nemateriální investice“, zejména do vzdělání a výzkumu. „Tato investice do inteligence sehraje podstatnou roli v rozvoji zaměstnanosti, schopnosti konkurence a solidarity našich zemí, "ř́ká se v předmluvě. ${ }^{10}$ Mưžeme tedy usoudit, že o rozvoj poznávacích schopností člověka půjde v Evropské unii především z důvodů ekonomických. O jiných než ekonomických cílech se zde hovoří na dalších místech (např. o hodnotě předávání kulturního dědictví Evropy, o důrazu na rozvoj individuální osobnosti žáka nebo o ochraně žáků před útoky informací v masmédiích, které zraňují lidskou důstojnost). V zásadě však lze říci, že jako celek je toto úsilí podřízeno cíli zvýšit konkurenceschopnost Evropské unie na světovém trhu. ${ }^{11} \mathrm{~V}$ tomto smyslu je kritizována mnoha západoevropskými pedagogy a označována za „neoliberalistickou“, tedy takovou, ve které jde především o podporu principu volné konkurence, přičemž stát zajistí pouze podmínky pro rozvoj tržních mechanismů.

\section{Klíčové kompetence Rámcového vzdělávacího programu pro základní vzdělávání jako výbava žáka pro spokojený a úspěšný život občana státu}

Rámcové vzdělávací programy se oproti dřívějším kurikulárním dokumentům věnují cílovým zaměřením školního vzdělávání ze dvou úhlů pohledu. Tím prvním je pohled pedagogů školy. Programy vymezují oblasti, ke kterým má pedagogické úsilí učitelů a vychovatelů na konkrétních školách směřovat. Základní vzdělávání má podle formulací Rámcového vzdělávacího programu pro základní vzdělávání (dále jen RVP ZV) žákům poskytnout spolehlivý základ všeobecného vzdělání orientovaného zejména na situace blízké životu a na praktické jednání. Pedagogové proto mají usilovat o naplňování těchto cílů:

- umožnit žákům osvojit si strategie učení a motivovat je pro celoživotní učení;

- podněcovat žáky k tvořivému myšlení, logickému uvažování a k řešení problémů;

- vést žáky k všestranné, účinné a otevřené komunikaci;

- rozvíjet u žáků schopnost spolupracovat a respektovat práci a úspěchy vlastní i druhých;

- připravovat žáky k tomu, aby se projevovali jako svébytné, svobodné a zodpovědné osobnosti, uplatňovali svá práva a naplňovali své povinnosti;

- vytvářet u žáků potřebu projevovat pozitivní city v chování, jednání a v prožívání životních situací; rozvíjet vnímavost a citlivé vztahy k lidem, prostředí i k přírodě;

10 (C) Weisbuch zur allgemeinen und beruflichen Bildung. Lehren und Lernen - auf dem Weg zur kognitiven Gesellschaft, s. 4 (on-line), dostupné na: http://europa.eu/documents/comm/white_papers/pdf/com95_590_de.pdf, citováno dne 16. 6. 2014.

11 Více srov. Ludmila MUCHOVÁ, Náboženská výchova ve službě české škole, Brno: Kartuziánské nakladatelství, 2005. 
- učit žáky aktivně rozvíjet a chránit fyzické, duševní a sociální zdraví a být za ně odpovědný;

- vést žáky k toleranci a ohleduplnosti k jiným lidem, jejich kulturám a duchovním hodnotám, učit je žít společně s ostatními lidmi;

- pomáhat žákům poznávat a rozvíjet vlastní schopnosti v souladu s reálnými možnosti a uplatňovat je spolu s osvojenými vědomostmi a dovednostmi při rozhodování o vlastní životní a profesní orientaci.

Druhým úhlem pohledu je odpověd' na otázku, jakých cílů mají dosáhnout sami žáci v oblasti svých vlastních schopností, dovedností a návyků, postojů a hodnot. Jestliže vnímáme cíl jako vše, co si žák osvojil na konci vlastního učebního procesu, hovoříme o „žákovských kompetencích". RVP ZV definuje šest klíčových kompetencí, k nimž mají žáci v průběhu školní docházky dospět. Kompetenci přitom definuje samotný rámcový vzdělávací program jako „Souhrn vědomostí, dovedností, schopností, postojů a hodnot důležitých pro osobní rozvoj a uplatnění každého člena společnosti. Jejich výběr a pojetí vychází z hodnot obecně přijímaných ve společnosti a $\mathrm{z}$ obecně sdílených představ o tom, které kompetence jedince přispívají k jeho vzdělávání, spokojenému a úspěšnému životu a k posilování funkcí občanské společnosti." ${ }^{12}$ Z pohledu RVP ZV tedy platí, že cíle, o který usiluje vyučující, je dosaženo nikoliv tím, že byly vzhledem k němu užity určité obsahy a metody práce, ale teprve tehdy, když se stane kompetencí žáků na konci jejich učebního procesu. Kompetence tedy odpovídají cílovým zaměřením pedagogů, ale nevyčerpávají se v nich, směřují k odpovědi na otázku, co si s obsahy a metodami zprostředkovanými učitelem počal samotný žák a do jaké míry je skutečně proměnil ve své vlastní nové kompetence. To je patrné již z jejich výčtu: kompetence k učení; kompetence k řešení problémů; komunikativní kompetence; kompetence sociální a personální; kompetence občanské; kompetence pracovní. Nejde tedy ani zdaleka pouze o to, kolik si žáci osvojili encyklopedických znalostí, ale jak se naučili s těmito znalostmi zacházet a využít jich k praktickému životu. RVP ZV tímto praktickým životem rozumí především spokojený a úspěšný život občana státu. Kritici celého systému bílých knih, ze kterého vzešel a ke kterému směřuje, ho podezřívají, že za snahou o přípravu žáků na uvědomělé občanství se skrývá především snaha o výchovu člověka ovládajícího především schopnost přizpůsobit se každým, především hospodářským podmínkám - být tvárnou, ale výkonnou pracovní silou.

\section{Vzdělávací standardy a problém vnější evaluace žákovských výkonů ve službě rozvíjení rozumových schopností žákư: tlak na výkon}

Vzdělávací standardy jsou v podstatě konkrétní testovací úkoly, jejichž vyhodnocení se dá dobře kvantifikovat. V příloze $\mathrm{k}$ RVP ZV jsou zpracovány pro dva ročníky, v nichž pravidelně dochází k testování žákovských kompetencí - pro 5. ročník, v němž završují žáci docházku na 1. stupni ZŠ, a pro 9. ročník, v němž žáci završují celou docházku na ZŠ. Např́iklad standardy pro vzdělávací obor český jazyk v 5. ročníku jsou rozvrženy do třech oblastí: komunikační a slohová výchova, jazyková výchova a literární výchova. Pro každou oblast je zpracováno několik testových úloh, celkem jich je kolem padesáti. Uvádím příklad:

Vzdělávací obor: Český jazyk; ročník: 5; tematický okruh: komunikační a slohová výchova; Očekávaný výstup RVP ZV: Žák čte s porozuměním přiměreně náročné texty potichu i nahlas. 
Indikátory:

- Žák navrhne vhodný nadpis.

- Žák posoudi na základě přečteného textu pravdivost/nepravdivost tvrzení.

- Žák posoudi, zda daná informace vyplývá/nevyplývá z textu.

- Žák vyhledá v textu odpověd' na zadanou otázku.

Následuje ilustrationí úloha. Výchozí text:

Téměr všechny myšlenky a objevy učiněné během věkư můžete nalézt v knihách. Kniha je jedním $z$ největších lidských vynálezů. Existuje mnoho druhů knih - od beletrie (např. povídky a romány) po naučnou literaturu (např. př́ručky, slovniky, encyklopedie). Proní knihu zhotovili Egyptané před 5000 lety. Byla napsaná na papyrových svitcích. Řimané vynalezli knihu, jak ji známe dnes. Pro stránky použili upravenou zvírecí kưži - pergamen. Po staletí se knihy psaly ručně. Byly vzácné a drahé. $V$ 8. století Ciñané vynalezli knihtisk. Do Evropy se rozšíril během 15. století. Knihtisk umožnil vyrábět větší množství knih. Dnes se při výrobě knih využívaji počitače, fotografické přístroje, stroje samy tisknou, skládají papir, sešívají jej a vážou do knihy.

1. Navrhni vhodný nadpis pro prečtenou ukázku.

2. Rozhodni na základě prečteného textu, zda uvedená tvrzení jsou pravdivá, či nepravdivá:

a) Dřive byly knihy vzácné a drahé, protože se psaly ručně.

Ano - Ne

b) V knihách je zaznamenáno mnoho di̊ležitých myšlenek a objevů.

$A n o-N e$

c) Existuje málo druhů knih, většinou jsou to encyklopedie.

d) Knihtisk se do Evropy rozšíril v 19. století.

Ano - Ne

Ano - Ne

3. Rozhodni, zda uvedená informace vyplývá, či nevyplývá z textu: Nejstarší známou česky tištěnou knihou je Kronika trojánská (1468).

\section{Jak se nazývá upravená zvírecí kůže, kterou používali Římané pro stránky knih ?13 $^{13}$}

Vidíme, že jde vlastně o přesnou operacionalizaci abstraktněji formulovaných žákovských kompetencí. Z původního tlaku české školy na osvojování encyklopedických znalostí se přesouvá tlak na intelektuální dovednosti manipulující s původní znalostí. Žáci mají vyhledávat informace, hodnotit je a navrhovat řešení problémů. $Z$ př́kladu je patrná snadná vyhodnotitelnost žákovské dovednosti pracovat s textem. $Z$ tohoto hodnocení se však nedozvíme nic o tom, zda děti takové činnosti zajímají, baví, zda je pro ně radost formulovat vlastní myšlenky tak, aby jim druzí dobře rozuměli, nebo dokonce aby vyjádřili své pocity, zážitky či zkušenosti nebo se setkali s krásou. Soubor testových úloh pưsobí sice velmi objektivně, současně však velmi chladně a vzhledem k zážitkovému světu dětí a mladých lidí cize. Už vůbec nic nevypovídá o tom, jak se díky takto získané schopnosti pracovat s textem mohou děti chopit vlastního života jako př́ležitosti naplnit svůj život smyslem. Bude-li se vyučující českého jazyka analogickým úlohám věnovat systematicky, naučí se je děti řešit celkem mechanicky, a tedy úspěšně. Postoupíme na žebříčku zemí v hodnocení PISA. Stačí to?

Mnozí pedagogové v zemích Evropské unie mechanismus testovacích standardů kritizují. Poukazují především na fakt, že sice v Bílé knize týkající se směřování školských systémů př́islušných zemí jsou zmíněny takové hodnoty, jako je rozvoj osobnosti žáka, jeho schopnost ko- 


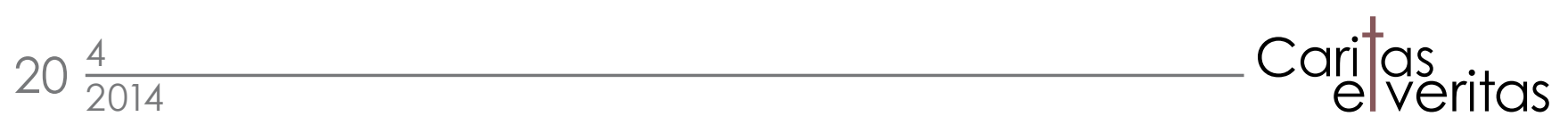

munikace nebo schopnost řešit problémy, že jsou však podřízeny tlaku na rozvoj rozumových schopností žáků za účelem jejich pozdější konkurenceschopnosti na trhu práce. Ze školy se tak podle nich stává území, které pro děti a mladé lidi vytváří především konkurenční prostředí a v jeho rámci tlak na výkon. Výkon ve srovnatelných situacích se také stává převažujícím kritériem hodnocení žáků. Obecné vzdělání a výchova k základním lidským hodnotám jsou tak např. podle W. Schöniga podřízeny zaměření na vzdělávací standardy. Škola pohybující se pod tlakem připravit žáky především na srovnávací testy postupně rezignuje na to, aby žáky vedla $\mathrm{k}$ citlivosti vůči vlastnímu nitru a k posilování jejich pozitivních stránek, aby se zaměřila na jejich schopnost zaujmout odstup a vzdorovat konzumním tlakům, eventuálně je kriticky reflektovat. Smyslem obecného vzdělání nejsou podle něho pouze znalosti aplikované na konkrétní problémové situace, ale také rozvíjení schopnosti hledat a nalézat vnitřní klid a rovnováhu se současným pevným a trvalým postojem vưči vlastní svázanosti s lidmi a světem. Schönig se domnívá, že př́lišné zdůraznění mezinárodních srovnání intelektuálních výkonů žáků je výrazem zájmů mezinárodního kapitálu o získání pracovní síly, která bude dostatečně flexibilní a tvořivá na to, aby podřídila vše kariérnímu postupu, jenž jí bude dovolen. Stejně tak má výčet kompetencí afirmativní charakter. Nemají smysl samy o sobě, ale pouze ve vztahu k výkonu, který je měřitelný, díky němuž na trhu práce osvědčí jednou takto vycvičení žáci schopnost osvědčit se v soutěži a společně s podobně úspěšnými dávat do pohybu flexibilní, ale anonymní funkční sítě. ${ }^{14}$

Ostatně jak ošidná je vnější evaluace založená na kvantitativních objektivně měřitelných ukazatelích, zažívá dnes a denně i každý vysokoškolský pedagog. Kvalita jeho publikační práce je měřena pomocí kvantitativních ukazatelů jako počet odborných článků v časopisech s doloženým vědeckým renomé. Konec konců kdyby autorka tohoto článku sledovala vážně cíl ukázat na ošidnost klíčových kompetencí užívaných v české kurikulární reformě po roce 2005 vzhledem k výchově k hodnotám dávajícím životu smysl, bylo by daleko vhodnější směrovat článek do populárně vědeckých pedagogických časopisů, kde by si ho měli šanci všimnout především nejzainteresovanější odborníci na tuto problematiku - samotní učitelé. Vzhledem k potřebě získat určité ohodnocení však je článek koncipován na úrovni, která dovolí jeho otištění v recenzovaném časopisu, jehož cesta $\mathrm{k}$ učitelům ZŠ je velmi málo pravděpodobná. Na tom je paradoxní především skutečnost, že samotné přírodní vědy, na jejichž území vznik1 tento tlak na kvantifikaci, a tudíž objektivizaci publikační činnosti vědců, dospěly poměrně rychle k morálním hranicím použitelnosti. Tak referuje časopis Respekt o prestižním časopisu Nature, který otiskl výsledky převratného výzkumu mladé japonské vědkyně Obokata ve spolupráci s týmem japonských a amerických vědců. Posléze se však ukázalo, že byly publikovány některé chybné nákresy a samotné popsané pokusy nejsou reprodukovatelné. Kvalita takovéhoto článku je tedy velmi diskutabilní. Naopak nositel Nobelovy ceny za fyziku P. Higgs dodává, že on sám by pravděpodobně nebyl díky své nízké publikační aktivitě pro nějakou univerzitu vůbec akceptovatelný. Tzv. Sanfranciský manifest potom požaduje, aby odbornost vědeckých př́ispěvků byla posuzována výhradně podle jejich obsahu, nikoliv podle toho, kde byly publikovány. ${ }^{15}$

W. Schönig se odvolává na E. Weinerta, který upozornil na příliš vysoká očekávání od evaluací srovnávajících výkony žáků. A sice proto, že žákovské výsledky bývají výrazem mnohem většího počtu faktorů, než je pouhá krátkodobá změna v didaktických opatřeních, která mění podmínky vyučování. Za takové považuje Weinert např. dlouhodobou atmosféru ve třídě,

14 Srov.Wolfgang SCHÖNIG, Die Schule des 21. Jahrhunderts als Raum der Bildung? - Nachdenken über die Engpässe der neoliberalen Schulreform, in: Kultur der Anerkennung. Würde - Gerechtigkeit - Partizipation für Schulkultur, Schulentwicklung und Religion, ed. Martin JÄGGLE a kol., Hohengehren: Schneider Verlag, 2013, s. 42-43.

15 Srov. Zdeněk SLANINA, Věda v kyselé lázni, Respekt, roč. XXV, s. 19-23. 
dlouhodobý styl výchovy, učení a komunikace, které se odvozují od pedagogického umění učitelů. Chceme-li tedy zlepšit výkony žáků, nemůžeme pouze měnit vyučovací metody, ale musíme počítat s tím, že se protínají s množstvím obecnějších pedagogických opatření. ${ }^{16}$

Od evaluací prováděných formou srovnávacích výkonových testů se obecně neočekává, že díky nim může dojít ke zlepšení pedagogických vztahů v prostředí školy, nýbrž že se díky nim rozmnoží a navýší „lidský kapitál“. Uspěchy či neúspěchy ve srovnávacích testech školy „ocejchovávají“. Tak se například dozvídáme ze zpráv, ve kterých krajích byly školy v PISA testech nejúspěšnější, ve kterých nejméně úspěšné. Co tato informace vlastně o zmíněných krajích a jejich školách vypovídá? Skutečnou úroveň vzdělanosti našich žáků a žákyň těmito testy měřit nelze. Výsledky testů vytvářejí tvrdá, objektivní data. Naopak data měkká týkající se lidské subjektivity, data kvalitativní, tak snadno změřit nelze.

V době, kdy vstupoval v platnost Rámcový vzdělávací program pro základní vzdělávání, byly jím jednotlivé školy zavázány pravidelně nejen hodnotit výkony žákůa, ale také provádět tzv. autoevaluaci. Vzhledem k výkonům žáků musely formulovat způsoby hodnocení (klasifikací, slovně nebo kombinací obou způsobů) a zveřejnit i kritéria hodnocení, autoevaluace měla být specifikována co do jejích oblastí, cílů, kritérií a nástrojů včetně časového rozvržení evaluačních činností. ${ }^{17}$ Ve verzi RVP ZV platné k 1. 9. 2013 už školy k provádění autoevaluace zavázány nejsou. Z kapitoly týkající se zásad, vyhodnocování a úprav školního vzdělávacího programu byla vypuštěna, zůstaly pouze požadavky na formulaci kritérií a forem hodnocení žáků. ${ }^{18}$ Zatímco tedy klíčové kompetence a jim odpovídající standardy jsou zaměřeny na evaluaci výkonu žáků, existuje široká oblast života školy, která souvisí s její výchovnou atmosférou. I ta se dá vyhodnocovat pomocí speciálních nástrojů. Abychom porozuměli jejich logice, musíme se zastavit u pojmů kultura a klima školy.

\section{Kultura a klima školy a problém vnitřní evaluace školy - pomoc na cestě výchovy $\mathrm{k}$ životnímu smyslu}

Zaměření na výkon žáků spojený s jejich pozděǰsí úspěšností na trhu práce není zdaleka jediným a nejdůležitější úkolem školy. Chceme-li však definovat, co všechno spadá do oblasti kultivace preferovaných hodnot, vzájemných vztahů a do př́ipravy na spokojený a št'astný osobní život uprostřed bližších či širších mezilidských vazeb, narazíme na pojmy kultura a klima školy. Pedagogové mají problém s jejich jednoznačnou definicí. Vybírám proto definici velmi obsáhlou pocházející z pera pedagoga, jehož letitým odborným zájmem je kultura školy. Podle M. Pola je tedy kultura školy „všudypřítomný a relativně stálý faktor života školy, který obsahuje přesvědčení a hodnoty, porozumění, postoje, významy, normy, symboly, rituály, ceremonie, preferovaná chování a který se projevuje v chování lidí ve škole. Zahrnuje zkušenostní základ a potenciál změny a kvality školy. Jeho jádrem jsou obvykle hodnoty. "19 Základními, nehmatatelnými prvky kultury školy jsou hodnoty, normy a vztahy.

16 Srov. Wolfgang SCHÖNIG, Die Schule des 21. Jahrhunderts als Raum der Bildung?, s. 44.

17 Srov. (C) Rámcový vzdělávací program pro základní vzdělávání (se změnami provedenými k 1. 9. 2007), Praha: VúP, s. 119 (on-line), dostupné na: http:/ / www.vuppraha.cz/wp-content/uploads/2009/12/RVPZV_2007-07.pdf, citováno dne 11. 6. 2014.

18 Srov. (C) Rámcový vzdělávací program pro základní vzdělávání (verze platná od 1. 9. 2013), Praha: MŠMT ČR, s. 135 (on-line), dostupné na: http:/ / www.nuv.cz/file/433, citováno dne 11. 6. 2014.

19 Pol citován podle (C) Danuše NEZVALOVÁ, Kultura školy a klima školy, Ostrava: Přírodovědecká fakulta UP, s. 12-13 (on-line), dostupné na: http://esfmoduly.upol.cz/texty/kultura_klima_skoly.pdf, citováno dne 11. 6. 2014. 
Klima školy je potom jev sociálního, skupinového charakteru. Vyčerpává se ve zobecněných postojích všech aktérů školy, v tom, jak žáci, učitelé i ostatní zaměstnanci vnímají vše, co se odehrává v budově, tř́idách a v pedagogickém sboru i ve zpơsobu, jak na to vše emocionálně reagují. Klima školy tedy budou zkoumat pedagogové ve spolupráci s psychology. Dobré školní klima by mělo vytvářet pro všechny zúčastněné prostor bezpečí pro společný život a rozvoj. Tak charakterizuje D. Nezvalová ve velmi výstižném studijním textu klima školy. Nalezneme zde také popis programu Škola podporující zdraví (ŠPZ). Můžeme ho použít jako ukázku, jak do autoevaluačních kritérií pro posouzení školy mohou prostřednictvím zkoumání kultury a sociálního klimatu školy zcela logicky vstoupit duchovní hodnoty. Cílem tohoto programu je podle zmiňované autorky vytvořit bezpečné a sociálně podnětné sociální prostředí v celé škole, v každé třídě, mezi žáky i mezi učiteli, a to na základě rozvíjení humanistických postojů, jimž bude odpovídat i jednání a chování všech účastníků školního života. Mezi základní humanistické postoje program ŠPZ řadí úctu, důvěru a snášenlivost; uznání, účast a empatii; otevřenost/vstřícnost; a konečně vůli ke spolupráci a pomoci. ${ }^{20}$

Kultura a klima organizace byly faktory, které původně začali zkoumat manažeři výrobních podniků a organizací zaměřených na generování zisku. Lepší sociální klima a kvalitní kultura organizace se totiž měly stát nástrojem pro zefektivnění práce a navýšení zisku. Konec konců někteří autoři - pedagogové a psychologové -, kteří vytvářejí evaluační nástroje pro zkoumání školního klimatu, se netají tím, že tomu tak je i v př́ípadě školy. Citujme například z úvodu pro učitele při zadávání dotazníku zkoumajícího klima školy autorů Urbánka a Chvály:

„Sociální klima v prostředí specifické organizace školy ovšem vedle možného vlivu na výkonovou úroveň výsledků přináší ještě další efekt, jakousi ,přidanou hodnotu', která je vlastní samému smyslu výchovy: příznivě vnímané sociální vztahy a procesy ve výchovné instituci představují totiž pro všechny její aktéry, a především pro žáky, vhodný a pro edukaci žádoucí model fungující komunity. Prožitková úroveň a zkušenosti žáka, které se v sociální rovině vydatně opírají o působení skrytého kurikula, jsou velmi efektivním nástrojem pro intervenci hlubších výchovných vrstev na úrovni postojů, názorů, přesvědčení, sdílených hodnot atd. Tento fakt může velmi významně přispívat $\mathrm{k}$ budoucí sociální a profesní orientaci dětí i v každém dalším potencionálním společenství, ve kterém se žáci budou dále nutně pohybovat. Z hlediska diagnostiky je sociální klima výhodným indikátorem kvality práce školy. Školní klima má komplexní povahu a z hlediska aktérů akcentuje vztahovou rovinu fungování školy." ${ }^{21}$

Autoři tohoto nástroje pro evaluaci školního klimatu tedy považují hodnoty, na které cílí hodnocení sociálního klimatu školy, za něco, co tvoří jakousi nadstavbu k základnímu požadavku na školu, kterým je zvyšování výkonové úrovně žáků. To však nemění nic na tom, že v nástrojích evaluace školního klimatu hledání přítomnosti řady zejména eticky zaměřených hodnot skutečně nacházíme. Ukázat to můžeme například na metodě stanovování priorit školy pomocí metody nazvané Dobrá škola autorů M. Pola a B. Lazarové.

Sada výroků, se kterými se zde pracuje, se dotýká hodnot a hodnotové orientace. Vybrala jsem ty explicitní: Učitelé se snaží, aby byli žáci pokud možno aktivní, učitelé plánují výuku s přihlédnutím k zájmům žáků, škola se snaží podporovat všestranný individuální rozvoj žáků, vedení školy pravidelně s učiteli diskutuje o hodnotovém systému školy, snaží se ke všem přistupovat spravedlivě, zaměstnanci školy jsou připraveni věnovat škole i něco navíc, 
vedení školy podporuje a povzbuzuje iniciativu zaměstnanců, škola dbá na estetickou úpravu školních tříd, odpovědnost za rozvoj školy nese každý jedinec, diskuse o hodnotách se řídí daným postupem a pravidly, o konfliktech se mezi učiteli otevřeně hovoří, má-li někdo odlišný názor na systém hodnot, může ho sdělit v otevřené diskusi, jednotlivcům se dostává podpory, pokud ji potřebují, učitelé naslouchají osobním problémům žáků, v učitelském týmu jsou respektovány projevy emocí, vztahy učitelů a žáků jsou otevřené, komunikace mezi učiteli je velmi otevřená. ${ }^{22}$ Hodnoty jsou v těchto výrocích, které se stávají v rámci evaluačního procesu předmětem diskuse především $\mathrm{v}$ učitelském sboru, formulovány na některých místech konkrétně (např. naslouchání osobním problémům žáků, odpovědnost za rozvoj školy nese každý jedinec, ochota udělat pro školu něco „navíc“ apod.), jindy poměrně obecně (např. diskuse nad jinými př́stupy k hodnotám apod.).

V zahraničí můžeme nalézt konkrétnější evaluační nástroje spojené dokonce s termínem „duchovní hodnoty“. E. Muroňová, která v rámci své disertační práce zkoumala identifikovatelnost a vyhodnotitelnost prrítomnosti duchovních hodnot $\mathrm{v}$ prostoru školy, vyšla $\mathrm{z}$ definice S. Kučerové: „Duchovní hodnoty jsou cílem samy o sobě, nejsou prostředkem ničeho mimo sebe. Podřadit je můžeme leda celku života jako nejvyšší integrativní ideji. Jsou možné jen jako niterné zážitky člověka, který opravdově touží vyrovnat se s problémy lidské existence. “ ${ }^{23}$

O spirituální (duchovní) dimenzi v kultuře školy E. Muroňová podotýká, že zahrnuje podoby spirituality jednotlivců - at' už žáků, pedagogických nebo jiných pracovníků školy, rodičů, architektů školy apod. -, kteří se na ní podílejí, kteří do ní vstupují nebo v minulosti vstoupili, ale je také odrazem spirituality společnosti, příp. užšího společenství obce, ve které se škola nachází. Spirituální dimenze, která je jejich souhrnem, se odráží ve všech rovinách kultury školy a jedinečným způsobem je pak zase více nebo méně př́znivá smysluplnosti instituce školy a životnímu smyslu těch, kteří školu vytvářejí. Spirituální dimenze je do školy "přinášena“, ve škole přítomná a ze školy také „odnášena“ jako plnění nebo neplnění určitého osobního nároku. Spirituální dimenze je pak podle této autorky - analogicky k duchovním hodnotám v každodenním dění školy přítomná třemi způsoby:

- Jako viditelná součást kurikula, např. jako vzdělávací obsahy v hodinách dějepisu, literatury, religionistiky, ale také jako existenciální otázky, které vyžadují reflexi $\mathrm{v}$ rámci výuky jakéhokoli jiného předmětu. $\mathrm{V}$ tomto smyslu je legitimní hovořit např́iklad o spirituálním rozměru kurikula.

- Jako dimenze kultury školy jako takové, která pak život školy ovlivňuje. V tomto smyslu je legitimní hovořit např́íklad o spirituálním rozměru vzdělávání.

- Jako skrytá součást kultury školy, kterou tvoří jednotliví aktéři školy, např. jako situace, které nastanou o přestávce a nějakým způsobem směřují ke smyslu života. ${ }^{24}$

Kromě toho popsala E. Muroňová empirický výzkum A. Martinové (2005), na jehož základě autorka kategorizuje spiritualitu podle jejích projevů ve společnosti na projevy spirituality směrující k sobě, k prožitku a harmonii, k jistotám, k sounáležitosti s lidmi, se světem a k překonání hranic. Muroňová během jednoduchého exploratorního výzkumu tyto výchozí kategorie poněkud modifikovala, operacionalizovala do konkrétních tvrzení a ověřila jejich identifikovatelnost v prostředí školy na dvou úrovních: reálné přítomnosti a na úrovni ideální představy učitelů. V závěrečné diskusi potom uzavírá: „Reflexe spirituální dimenze v prostoru

22 Srov. Milan POL - Bohumíra LAZAROVÁ, Dobrá škola. Metoda pro stanovení priorit školy. Evaluační nástroje, Praha: Národní ústav odborného vzdělávání, 2011.

23 Stanislava KUČEROVÁ, Člověk - hodnoty - výchova. Kapitoly z filosofie výchovy, Praha: Vydáno vlastním nákladem, 1996, s. 77.

24 Srov. Eva MUROŇOVÁ, Spirituální dimenze kultury školy na základní škole na príkladu ČR, Brno: PF MU, disertační práce, 2011 , s. 96. 


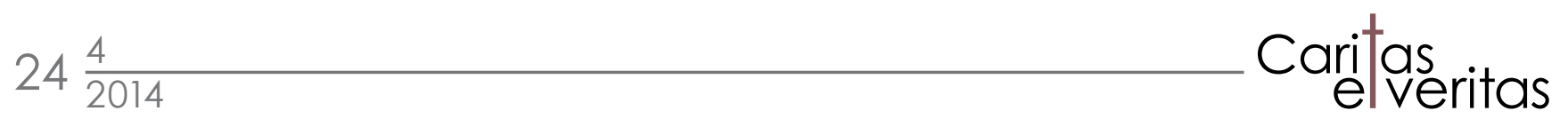

školy přináší antropologicky podstatné kvality potřebné k integraci osobnosti, které jsou dány rozvojem identity člověka a souvisejí s pocitem životního smyslu, zacílení života a jeho naplnění vůči tomuto poslednímu cíli. Reflexe spirituality znamená pro české školství například reflexi kategorií, jako je vděčnost za dar života, který je ve své podstatě jedinečný (kategorie 1), život ve všech rovinách, tedy s radostmi i bolestmi (kategorie 2), ocenění krásy a harmonie (kategorie 3), hodnota vnějších hranic a rituálů přinášejících orientaci a jistotu (kategorie 4), sounáležitost s lidmi a hodnota obětování se (kategorie 5), úžas, ale také pokora s vědomím vlastních hranic (kategorie 6), přijetí odpovědnosti z hlediska osobních, ale i nejširších globálních cílů (kategorie 7). " ${ }^{25}$ Vidíme, že kategorie E. Muroňové vlastně jen rozvíjejí logoterapeutický model tří cest k naplnění života smyslem.

\section{Závěr}

Co jsem chtěla touto úvahou říci? Že jsme v PISA testech nedopadli zase tak špatně - umíme vybavit žáky do konkurenčních bojů na trhu práce průměrně tím, že orientujeme výuku na získávání znalostí a na jejich rozumové zpracování, které se později projeví v konkrétních situacích zejména na trhu práce. Jak ukazují zkušenosti mnoha rodičů vyučujících své děti v domácí škole, znalosti pro budoucí povolání a dobrou pozici v konkurenci ostatních lze získat prostřednictvím médií nebo $\mathrm{v}$ rámci programového vyučování zcela samostatně a mnohem rychleji a zábavněji než ve škole. Takové děti se však nedostanou do prostoru, který je mnohem širší než prostor vlastní rodiny a ve kterém mají možnost navázat mnohem širší sociální kontakty, konfrontovat se s velikou škálou duchovních hodnot, eventuálně začít prověřovat, jak obtížný je úkol tyto hodnoty si uspořádat a v jejich jménu naplňovat vlastní život smyslem. Příprava na budoucí povolání, které budou současní žáci a žákyně osvědčovat v celosvětové konkurenci, je zcela jistě velmi důležitým úkolem školy. Ukázala jsem, že tento úkol vyplývá především z dokumentů EU zaměřených na hospodářský růst a konkurenceschopnost jednotlivých zemí. Vedle tohoto „ekonomického nároku“ jsem však upozornila na nárok „výchovy ke smysluplnému životu“, jak ho představuje např. logoterapie. Tento nárok ukazuje, že přinejmenším stejnou pozornost jako zvyšování konkurenceschopnosti žáků - budoucích občanů - na trhu práce bychom měli věnovat pedagogické duchovní atmosféře, jaká na českých školách panuje. Vytvoření přátelského prostředí, ve kterém se všichni žáci - s nejlepšími výkony i s výkony podprůměrnými - cítí být přijati a akceptováni takoví, jací jsou, ve kterém cítí připravenost učitelů i spolužáků podat pomocnou ruku, ve kterém vědomě a s radostí participují na životě své školy a ve kterém se učí přijímat bolesti života, odpouštět, dávat a zažívat lásku, je dlouhodobý úkol, jehož naplnění stojí čas a energii. Možná, že v takové atmosféře ubude jednostranných tlaků na zlepšování výkonu žáků, kteří tak nezažijí mimořádný úspěch ve srovnávacích testech výkonu. Nepřipraví-li však škola děti špičkově na konkurenční boj, ještě to neznamená, že je nepřipraví na život, jehož součástí sice zaměstnání a práce bezesporu je, ale nikoliv jedinou součástí, dáme-li za pravdu logoterapii. Důležitější než množství vydělaných peněz bude $\mathrm{v}$ budoucnosti pro naše děti i schopnost být věrný $\mathrm{v}$ lásce, trpělivý v pomoci nebo umění odpustit a dovolit lidem kolem sebe nový začátek. To jsou totiž předpoklady k prožití života naplněného smyslem, o kterém právě logoterapie říká, že ho lze realizovat pouze v nasazení se pro hodnoty ležící mimo vlastní prospěch člověka. Otázka, kterou položil V. E. Frankl lidem obecně, dostává v prostředí školy novou tvář. Je to zpochybňující tázání se po smyslu vychovávání a vzdělávání dospívající generace pro budoucí zisky společnosti i její vlastní, nebo dokonce po úsilí o vlastní seberealizaci na úkor druhých. Ukázala jsem, že zaměřit se na duchovní rozměr školního života lze dokonce i za pomoci konkrétních evaluačních 
nástrojů, které mají české školy k dispozici. Na školách to však dnes opět nikdo nepožaduje, a tak toto téma rychle vymizelo i z akademických diskuzí. Pečlivě objektivně hodnocené publikace odborných pedagogů si tak nacházejí problémy nové, snad snáze uchopitelné.

Zefektivňování vlastních výkonů a naplňování vlastního života smyslem jsem představila jako dva úkoly školy, které si nemusí navzájem odporovat. Pro oba má česká učitelská veřejnost $\mathrm{k}$ dispozici evaluační nástroje. Otázkou zůstává, jaké důvody mají autoři RVP ZV k tomu, že k aktivnímu využívání jednoho z nich přestaly školy motivovat.

\section{Má školní vzdělávání smysl, jestlliže nevede k hledání smyslu?}

Abstrakł Článek uvádí do souvislosti charakteristiku postmoderní evropské společnosti, změněné nároky na výkon žáků ve školách Evropské unie a logoterapeutický pohled na člověka hledajícího smysl života. Autorka konstatuje nesoulad mezi ekonomickým a politickým tlakem na školské systémy pripravovat žáky pro budoucí konkurenceschopnost svých zemí na světovém trhu práce a úsilím člověka o naplnění života duchovními, nemateriálními hodnotami. Upozorňuje, že se tak děje i přesto, že duchovní a sociální klima školy Ize vnímat a měnit za pomoci autoevaluačních nástrojü.

Klíčová slova postmoderní společnost; logoterapie; kultura školy; sociální klima školy; klíčové kompetence; standardy

\section{Is School Education Meaningful If It Does Not Lead Pupils to Seek Meaning?}

Abstract The paper links the characteristic of postmodern European society, the changed demands on pupil performance in EU schools and the logotherapeutic view of the human being seeking the meaning of life. The author states the discrepancy between the economic and political pressure on school systems to prepare pupils for the future competitiveness of their countries in the global labour market and human effort to fill life with spiritual, nonmaterial values. She points out that this happens even though the spiritual and social climate of schools can be perceived and changed with self-evaluation tools.

Keywords postmodern society; logotherapy; school culture; social climate of school; key competencies; standards 